In this issue:

Annual Report of the President, 1974-75

Letters

ACRL Internship Program . 215

Inside Washington . . . . 217

News From the Field . . . 220

People . . . . . . 229

Classified Advertising . . . . 231

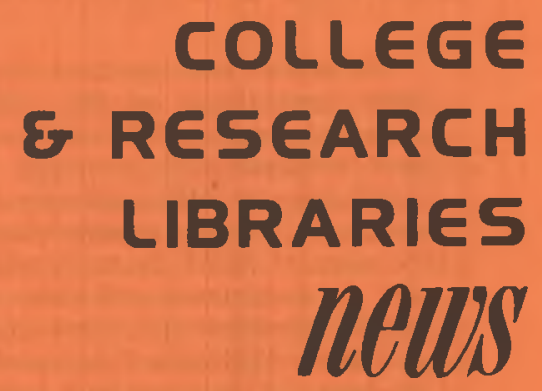

NO. $7 \bullet$ JULY/AUGUST 1975

\title{
Annual Report of the President, 1974-75
}

During 1974-75, ACRL continued to respond to issues more or less dictated by the changing economic and social conditions of the late 1960s and the first years of the present decade. Substantial progress was achieved in the area of developing standards for community college and college libraries which clearly recognize the need for a total integration of traditional library services and a wide array of new educational technology. The pursuit of the elusive goal of full faculty status for all academic librarians continued to be a major ACRL goal and the problem of governance in all of its intriguing complexity was debated and explored through traditional and nontraditional media.

Perhaps of more significance than many will realize are the exciting plans for the Centennial Convention developed by the Rare Books and Manuscripts Section for a display of books and documents which contain the political and philosophical corpus of ideas which produced the unique experience in self-government known as the United States of America. In addition to recreating an awareness that there was a time in history when America's position in the world rested on the intellectual and moral quality of its leadership, this outstanding display gathered from libraries all over the world hopefully will serve to remind the entire profession of its own intellectual and humanistic origins and responsibilities-something that is sometimes forgotten in the headlong rush to embrace, in toto, the fantastic tools of a technologically oriented society. Perhaps, indeed it is to be hoped, the outstanding historical display planned by the Rare Books and Manuscripts

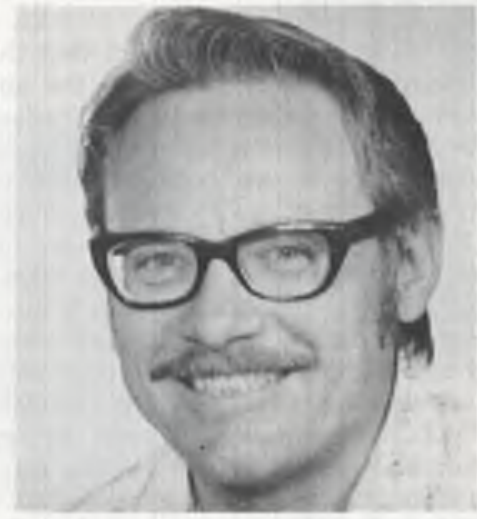

H. William Axford

Section may cause some reflection on the fact that not all revolutions, irrespective of their origins, produced the kind of results which burst upon the world on July 4, 1776. That historic event had long roots in the intellectual life and hopes of Western man and represented in its finest sense the ringing challenge of a rational and humanistic idealism to a basically cynical world. Perhaps, just perhaps, the exhibit will serve as a reminder that the past has meaning for the individual librarian as well as the historian, the archivist, and the antiquarian; as without it the possibility of self-understanding and self-renewal is impossible.

In this latter connection, the latest trends in membership are both encouraging and discouraging. Very encouraging is the fact that one out

Continued on page 216 
Travis, periodicals librarian, Florida Memorial College, Miami, are the second-year interns.

During the period of the internship, which ranges from six to nine months, each intern will work closely with the director of a major academic library. The host libraries in the second year of the program are Austin Peay State University; Eastern Michigan University; Oberlin College; State University of New York at Albany; Syracuse University; the University of California, San Diego; the University of Massachusetts, Amherst; and the University of Wisconsin, Milwaukee. The Mellon Foundation grant provides salaries, benefits, and approved expenses for the intern. The host library provides the training experience. Several workshops for the participants are also planned.

Applications from librarians and host institutions were reviewed by the project's advisory committee, chaired by Virginia Lacy Jones, dean, School of Library Service, Atlanta University. Other members of the committee are: Phyllis B. Cartwright, Miami, Florida; Richard M. Dougherty, University of California, Berkeley; James F. McCoy, Hudson Valley Community College; Annette L. Phinazee, North Carolina Central University; Katharine M. Stokes, Alexandria, Virginia; and David C. Weber, Stanford University. Casper L. Jordan, university librarian, Atlanta University, serves as project director. Beverly P. Lynch, executive secretary, Association of College and Research Libraries, is principal investigator. Applications for the third year of the program are now being received. All inquiries should be addressed to Mr. Casper L. Jordan, University Librarian, Trevor Arnett Library, Atlanta University, Atlanta, GA 30314.

\section{Annual Report}

Continued from page 213

of every five individuals who have joined this year is a new member. Very discouraging is an absolute loss of membership over the previous year, the impact of which is somewhat softened by the new dues structure of ALA, which has produced slightly increased operating revenues.

The number of new members and the extraordinary interest which has developed in recent months in the establishment of local and regional chapters are clear indications that ACRL is experiencing a new surge of vitality which, if properly nourished, could within a relatively short time produce a solidly based grass roots organization. This is the crucial issue. During my term of office it has become unavoidably clear that it is at the local level where the gut issues of academic librarianship will be solved and that out of this arena will come ACRL's future leaders.
One of the most discouraging aspects of my term of office has been knowing of the great number of interested individuals who would like to serve the organization in some way and the organization's inability to exploit this resource within its present structure. A nationwide network of local and regional chapters, on the other hand, would provide opportunities for all with a serious interest in advancing the goals of the profession. The role of the parent organization would be to nourish and sustain these chapters through the provision of a wide array of services which cannot be produced at the local level, e.g., speakers, consultants, and an arsenal of program materials utilizing a variety of formats.

Clear evidence of what can be done along these lines can be seen in ACRL's two preconferences for the San Francisco convention; one on the problems, challenges, and opportunities of collective bargaining sponsored by the Academic Status Committee and one on issues in eighteenth-century bibliography under the auspices of the Rare Books and Manuscripts Section. Reflected in these programs is ACRL's ability to bridge the scholarly, professional, and institutional interests of academic librarians. They represent, in the finest sense, the profession's intellectual interests and capabilities and its ability to respond to the social, political, and economic forces which are molding a new internal and external environment.

Perhaps the upward trend in new memberships indicates an awareness of this. In any event, one can hope so and urge ACRL to do everything possible in the months immediately ahead to support the development of a network of local chapters where the problems and issues discussed and debated at the national meetings can continue to be dealt with after the convention itself has become history, and out of this process produce new problems and issues to bring before the profession and the leaders needed to galvanize ACRL into action.

H. William Axford

President, ACRL

\section{New Addition}

A ground-breaking ceremony was held recently at the University of Hawaii for an addition to the Thomas Hale Hamilton Library. The appropriated funds included $\$ 10,800,000$ for the building and $\$ 1,200,000$ for equipment and furniture. This six-story addition will increase the total gross area of the library by 167,200 square feet. 